\title{
A Study on Accounting of Transfer Pricing and Its Effect on Taxation
}

\author{
Dr. Metin Uyar (Ph.D.) $)^{1}$ \\ ${ }^{1}$ Social Sciences Institute, Arel University, İstanbul, Turkey (Part time lecturer in Accounting) \\ Correspondence: Dr. Metin Uyar, Social Sciences Institute, Arel University, İstanbul, Turkey. E-mail: \\ strongfitsdr@gmail.com
}

Received: January 29, 2014

Accepted: February 14, 2014

Online Published: February 15, 2014

doi:10.5430/afr.v3n1p79

URL: http://dx.doi.org/10.5430/afr.v3n1p79

\begin{abstract}
The dimension of accounting of transfer pricing as one of the essential instruments of profit transfers between businesses has not been studied sufficiently. In this study, a review was conducted on occurrence of transfer pricing and how accounting transactions will be conducted required to be conducted by the entities. However, it is evaluated how transfer pricing will affect corporate tax via a case study. In order to make the study more concrete, the conceptual framework was revealed in the light of previous literature and accordingly a scenario was developed. In line with information in the scenario developed, it was indicated first how transfer pricing was conducted, and then a recommendation was stated in the accounting records required to be conducted for improvement by the entities. However, tax effect of the present case was determined before and after adjustment. According to such, it is concluded that related parties of transfer pricing should follow a record process considering simultaneous movement form and off-balance sheet accounts in adjustment transactions.
\end{abstract}

Keywords: Transfer pricing, Tax effect, Accounting entry, Adjusting entry, Subsidiary company, Parent company

\section{Introduction}

In this study, it is analyzed via literature review and case study how companies transfer profit through transfer pricing and how such effect on taxation. In the recent period, transfer pricing subject gaining importance being one of the agenda items related to modern accounting or cost management and through increase of national and international firms is an issue to be studied (Tippett \& Wright, 2006). Conveyance of the profit to the intended place through price differentiation in the purchase-sale transactions of goods or services of the business entities realized with the related parties. The aim of transfer pricing is to maximize the value of the corporation. The internal goals of a transfer pricing system include performance evaluation of subsidiaries and their managers, motivation and goal (behavioral) congruence (Abdallah, 2004). (Transfer prices may apply to departments, divisions, subsidiaries, or affiliate business units (Cravens, 1997).Transfer price can be an effective tool for companies to achieve many different objectives, such as profit maximization, cash flow management, marketing strategy implementation, production coordination, and employee motivation. For example, a multinational company might need to keep the import price of its foreign subsidiary at a low level so as to enable it to enter a new market, obtain a target market share, or maintain a certain product mix. Among the various objectives, achieving maximum corporate-wide profit and divisional evaluation are often cited by managers as the most important goals of transfer pricing. Interestingly, these two objectives are often in conflict with each other. Since transfer prices provide valuation for trade between divisions inside a company, they inevitably affect the divisional profit. Supposedly the transfer prices facilitate coordination between, and performance measure for, the divisions.

The companies have every incentive to use transfer price to move profit between tax jurisdictions with differential tax rates, thus minimizing total corporate tax. A parent company in a high tax country can purchase goods from its subsidiary in a low tax country at a price substantially above the market price. The subsidiary will report high profit, which will be taxed at the lower rate. The parent company will report a low profit, or even appear to be in financial distress. Hence the multinational companies will benefit from the lower global tax expense. The tax authority of the subsidiary will not object to the transfer price, since their tax revenue is increased by an artificially high profit, but the tax administrators of the parent company will find the existing transfer price and lost tax revenue objectionable (Wong, Nassiripour, Mir \& Healy, 2011). Transfer pricing is a pricing strategy on products, semi-finished products or components transferred between the related parties or the units in order to review the compliance with the purpose and ideal performance based on maximum profit and minimum tax (Borkowski, 1997). Transferring the transfer 
pricing to the accounting records due to such important bases is of great importance for applications, researchers and professionals. Literature scanning and applicable laws are studied first following the study, and then the transactions are recorded in the books providing with daily samples. Lastly, negotiation and results are evaluated.

\section{Literature Analysis and Conceptual Framework}

Transfer pricing is a response to decentralized organizational structures under which "responsibility centers trade amongst themselves" (Grabski, 1985). This is defined as the price paid in a business transaction, whether for; tangible property, intellectual property or the provision of services - between companies under related party control (Abdallah, 2004). The transfer price of these tangible and intangible resources is becoming an important issue in international supply chains, as decisions on policies to guide pricing decisions become increasingly complicated. Transfer pricing has area of application in holdings, company groups and large entities and departments operating at international level as it is applied interdepartmental level of a business entity. The subject of transfer pricing may be established on raw materials, commercial materials, services, projects, patents and licenses. Multinational businesses may reduce tax burden for shifting the profits to the countries applying lower tax rates through transfer pricing. The purpose is to concentrate profits of the related businesses on the other area of operation. In this manner the opportunity of the related parties to conduct auto-financing through transfer pricing is increased.

In Cravens (1997), it is observed that multinational companies have purposes such as motivation and competition statuses in their application of transfer pricing. However, such tendency brought some tax problems. Indeed the most important feature of transfer pricing is its effect on tax side. Therefore, a price policy shall be applied to increase performance of both parties in determining price. In this manner, it is aimed at preserving the competition power. As these prices are the most suitable prices for the benefits of the entity, the tax dimension thereof establishes problems for governments. In classical transfer pricing, generally cost based transfer pricing is used. Operation based costing method is used to response criticisms in linking the indirect production expenses with the finished products. The expenses of the operations conducted in production phase conduct faulty calculation of the costs of products, markets and customers since they are loaded without considering the properties of the market and customers. A department manager considering not making any new investment would desire to sell some part of the products to other departments of the company in the vertical integration structure. The company policy shall require such inter-departmental sales to be discounted. Other departments shall purchase such product with pleasure and shall make payments at lower prices. Such a behavior shall increase the earnings of the purchasing department and the firm as a whole (Adams \& Drtina, 2008). Samuelson (1982) demonstrated that the market prices of the intra-company traded goods, and the resultant transfer prices, can be affected by production and sales decisions by the companies. Eden (1983) used a partial equilibrium model to analyze the effect of the Canadian tariff regulations on company transfer prices. He found that the companies can change their production levels to counteract the effect of the tariff regulation. Halperin \& Srinidhi (1987) extended Samuelson's model to examine the effect of alternative transfer pricing methods specified in the U.S. Section 482 tax rule, namely, non-market resale price and cost-plus price. Prusa (1990) reached similar conclusions by using information economics theory, where the companies and the tax authority possess asymmetric information. In summary, researchers found that companies can often change their environmental, marketing, and production decisions to manipulate the arm's length transfer price. Alfons (2009) provided empirical evidence that multinational companies did shift profit to their German affiliates when their host country tax rates were higher than that in Germany. Clausing (2003) states that the reason for harsh measures related to transfer pricing in the US being one of the leading countries in terms of transfer pricing volume is the fact that approximately $40 \%$ of all trade consists of the trade between the related parties or another say trade operations between the partners.

Some researchers (Anctil \& Dutta 1999, Smith 2002, Baldenius, Melumad \& Reichelstein, 2004) recommended decoupling, that is, using different transfer prices for tax and performance evaluation purposes. However, big size companies are reluctant to use two sets of books lest that tax authorities might question the validity of the prices reported on their tax returns. Some researchers used an empirical approach to find out managers' perceived relative importance of the various objectives and constraints in transfer pricing strategies. Burns (1980) received surveys from 62 of the Fortune 500 firms. She concluded that the five most important variables were: U. S. market conditions, level of competition in the foreign country, maintaining reasonable profit for the foreign subsidiary, U.S. taxes, and economic conditions in the foreign country. In a study related to international level transfer pricing it is stated that it is a common method in provision of any and all goods, services, financial and non-financial assets between the firm members in the different areas of the world (Elliott \& Emmanuel, 2000). The price applied, in exchanging goods or services between the headquarters of the firm and its branch abroad or between branches in two different countries, is the international transfer pricing. In Chan \& Hung-Chow (1997), it is stated that there was no sufficient experience 
and opportunities about transfer pricing, however, since sufficient levels were not attained about the conceptual framework it is concluded that developing countries are more fragile. It is seen that different techniques are used in defining transfer pricing. Most notable ones of such techniques are cost based pricing, market based pricing and bargaining based pricing. It is required to consider the effects of some factors in selection of the method to be applied in defining the transfer pricing. Li \& Ferreira (2008) suggest a detailed model in this subject. According to the model, the factors effecting on transfer pricing are nature of internal transfers, internal technological environment, internal social environment, external technological environment and external institutional environment.

\section{Methodology and Application}

The method of this study includes sample case review. A case study is conducted below pursuant to the opinion that it was not studied how transfer pricing will be recognized in the accounting records as stated in the above section "Introduction and Conceptual Framework", developing an advice in accounting of transfer transactions, and the tax effect has been revealed as per such advice. It is seen that transfer pricing in accounting system has two fundamental structures. One of them is OECD transfer pricing guide. The other one is IAS 36 ( International Accounting Standard 36: Impairment of Assets).

The concept of Camouflaged Earnings through Transfer Pricing is defined in the different countries laws as Turkey, Germany, England: If the entities will sell or purchase goods of services at a price or consideration determined violating the principle of arms length prices, the earnings shall be deemed as distributed as camouflaged fully or partially through transfer pricing. Purchases, sales, production and construction transactions, leasing and subletting transactions, lending or loaning funds and other transactions requiring salary and other similar payments are considered as good or service purchase or sales in any circumstance and conditions." In IAS 36, the unit generating cash is defined as the subject of transfer pricing. The smallest noticeable asset group generating cash independent of cash inflows from the other assets or other asset groups is defined as the unit generating cash. The standard, related to impairment test of the cash generating unit utters intercompany transfers in determination of the cash flows. If the cash inflows generated by an asset or cash generating unit shall be affected from the intercompany transfer pricing applications, the company is required to apply the most possible price estimate (estimates) expected to be occurred in the future in a transaction to be conducted in mutual bargaining environment in estimation of the followings. It was not seen how transfer pricing will be recorded in accounting and where it will be placed in national/ international accounting standards. The following examples establish a solution proposal related to accounting of transfer pricing.

\subsection{Sample Case and Accounting}

Scenario: An electronic company listed 5000 units of the products having the unit cost of $\$ 50$ at the sale price of $\$ 42$ to one of its subsidiary company. And it sold 10,000 units to a non related customer at $\$ 60$ in line with the equivalent price. The firm as being the subsidiary sold 4,000 pieces of such units to another firm at $58 \$$. The parent company is within $20 \%$ tax slice as the subsidiary company is subject to $15 \%$ tax since it has tax benefits granted to its specific geographic area.

The General Journal of the Parent Company

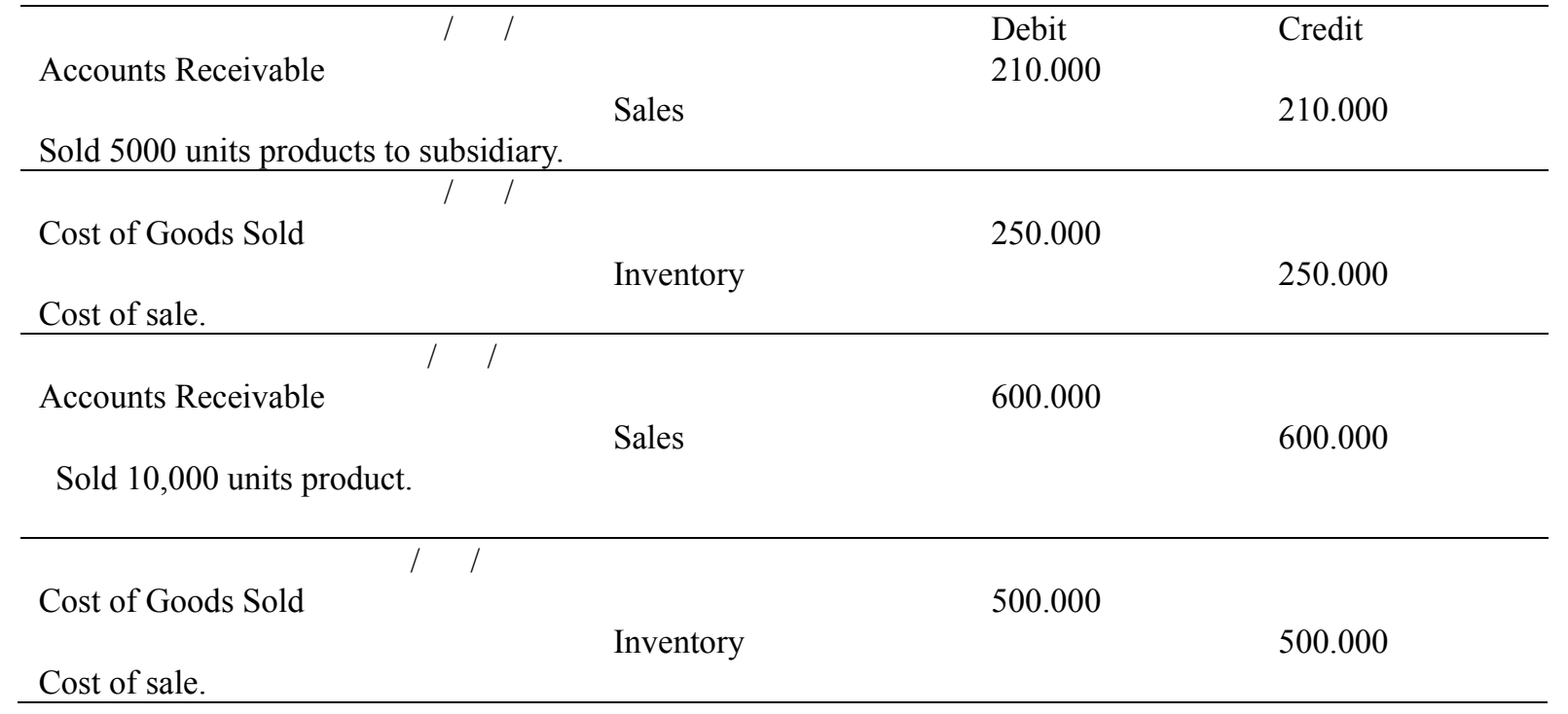


The General Journal of the subsidiary (Related Party)

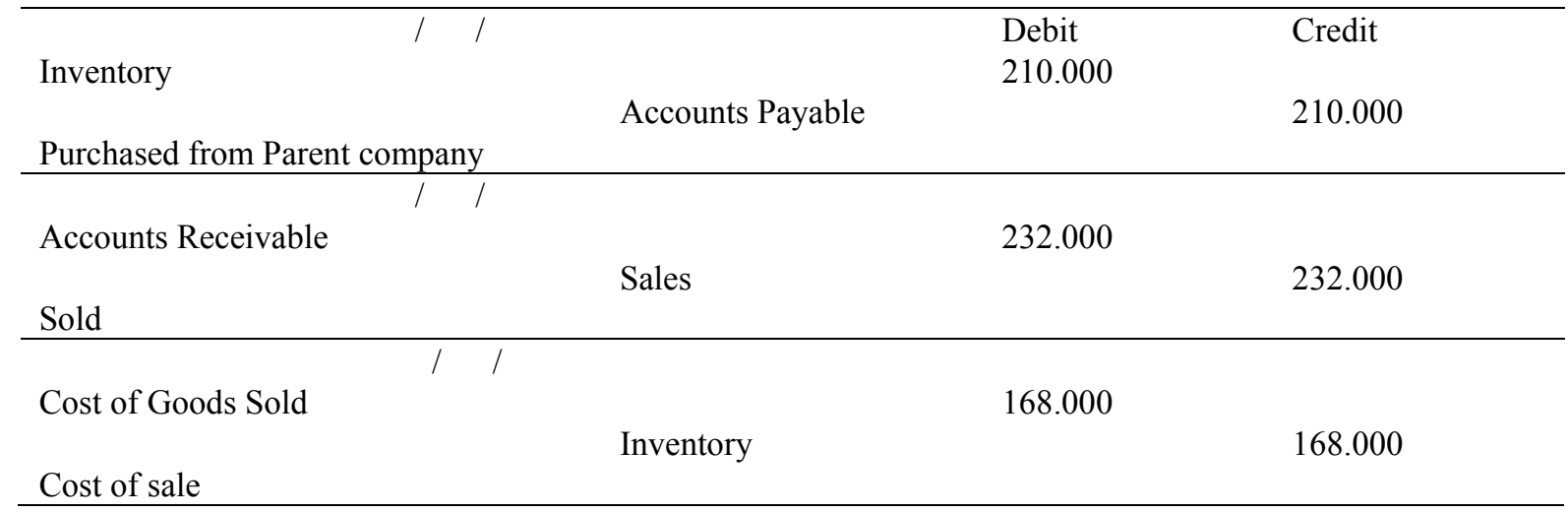

As you may see, the parent company applied different price to its affiliate as it applied another price to a non related customer. Therefore the calculation of profit or loss shall be as per the Table 1.

Table 1. Calculation of Tax for the Period

\begin{tabular}{llll}
\hline Panel A: The Parent Company’s Tax & \multicolumn{3}{l}{ Panel B: The Subsidiary’s Tax } \\
\hline Revenue & $\$ 810.000$ & Revenue & $\$ 232.000$ \\
Expense & $\$ 750.000$ & Expense & $\$ 168.000$ \\
Taxable Income & $\$ 60.000$ & Taxable Income & $\$ 64.000$ \\
Tax 20\% & $\$ 12.000$ & Tax 15\% & $\$ 9.600$ \\
\hline
\end{tabular}

In the Table 1 Panel $\mathrm{A}$ it is seen that the company provides $810,000 \$$ income from its main operation and its expenses are $750,000 \$$ causing tax accrual of $\$ 12,000$. According to the Panel B, although the affiliated firm obtained more profit it was subject to less tax accrual due to its tax benefits. Total tax amount required to be paid by two companies is determined as $\$ 21,600$. In another say, camouflaged earnings was provided through transfer pricing. The profit was transferred from the parent company to the affiliated company. Due to such transaction being possible to be found out in any possible tax reviews the parent company and the affiliate should conduct adjustment related to the tax. Conduct of the adjustment (correction) transactions shall be changed by the period of determination of the camouflaged earnings distribution through transfer pricing method. There are three possible scenarios available such as noticing the distribution of camouflaged earnings in the same provisional tax period, noticing the distribution of camouflaged earnings in the next provisional tax period, and noticing the distribution of camouflaged earnings in the next year.

\subsection{Adjustments and Their Effects on Taxation}

The recording of the parent company should be as following if noticed within the same provisional tax period or at the end of the period.

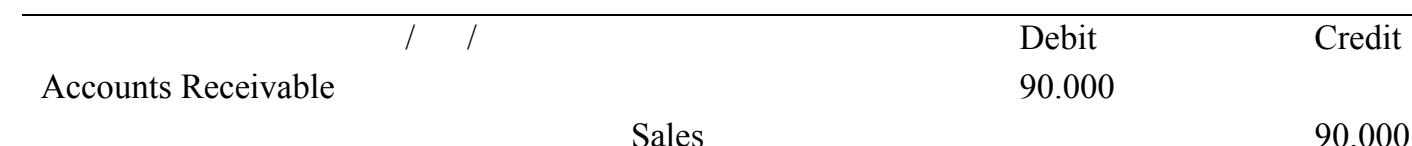

Adjusting entry

The recording by the subsidiary shall be as following.

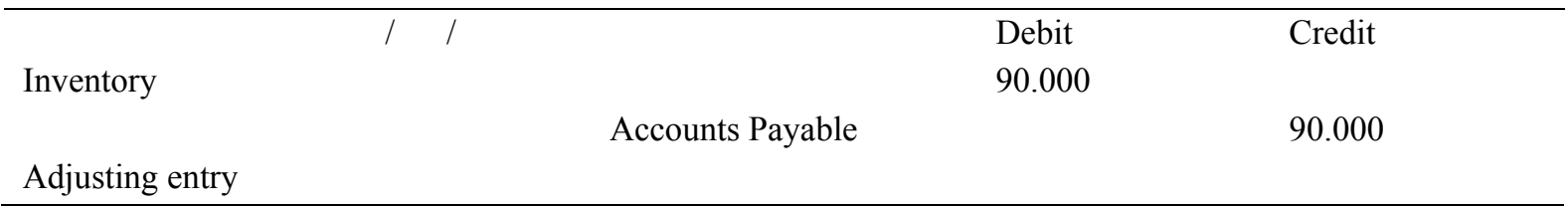


The Parent Company shall make account correction through adding it to the off balance accounts and adding to the earnings for the period. In such a case, the calculation of the new tax shall be as per the Table 2 .

\begin{tabular}{|c|c|c|c|}
\hline \multicolumn{2}{|l|}{$1 /$} & Debit & Credit \\
\hline \multicolumn{2}{|c|}{ Non-deductible expenses debited account } & 90.000 & \\
\hline \multicolumn{2}{|c|}{ Non-deductible expenses credited account } & & 90.000 \\
\hline \multicolumn{4}{|c|}{ Off balance accounts- Adjusting entry } \\
\hline \multicolumn{2}{|l|}{$1 /$} & Debit & Credit \\
\hline \multicolumn{2}{|c|}{ Deductible revenues debited account } & 90.000 & \\
\hline \multicolumn{2}{|c|}{ Deductible revenues credited account } & & 90.000 \\
\hline \multicolumn{4}{|c|}{ Off balance accounts- Adjusting entry } \\
\hline \multicolumn{4}{|c|}{ ble 2. Post-Adjustment Tax Effect } \\
\hline \multicolumn{2}{|c|}{ Panel A: The Parent Company's Tax } & \multicolumn{2}{|c|}{ Panel B: The Subsidiary Company’s Tax } \\
\hline Income & $\$ 60.000$ & Income & $\$ 64.000$ \\
\hline Non-Deductible Expenses & $\$ 90.000$ & Deductible Revenues & $\$ 90.000$ \\
\hline Taxable Income & $\$ 150.000$ & Taxable Income & $-\$ 26.000$ \\
\hline Tax $20 \%$ & $\$ 30.000$ & Tax & - \\
\hline
\end{tabular}

In the Table 2 Panel A, the parent company was forced to add $\$ 90,000$ to the earnings of the business previously calculated. The reason for such increase is the increase in the cost of the goods sold. With addition of expenses of $\$ 90,000$ as non-deductibles, the tax of the new business increased to $\$ 30,000$. Therefore, there is an increase of $\$ 18,000$. Otherwise, tax loss fine shall be charged on the company for the loss of tax being $30.000-12.000=18.000 \$$ and delay penalty shall be applied on the original tax as per the applicable provisions of the laws. In Panel B, the affiliate shall be relieved of the additional corporate tax burden through correction with the adjusted corporate tax return. As the tax amount required to be paid by both companies was 21.600\$ $(12.000+9.600)$, $\$ 8,400$ lower tax collection from both firms in aggregate would be prevented. In this manner, the losses of the government shall be reduced.

\section{Conclusion}

In this study, it was reviewed how the entitled distribute camouflaged earnings through transfer pricing and how it affects the taxation. A scenario was prepared to conduct the analysis and accounting solution proposal was realized for the case presented in such scenario. Transfer pricing is pricing of goods or services provided from a department of a business entity to other departments within the same business entity (Garrison \& Noreen, 2000).In another say, it is pricing of purchase-sales between the departments of a business entity structured in the form of decentralized management. The goods or services transferred between the departments in the business being subject to transfer pricing are called interim goods (Hongren et al., 2000). Transfer of interim goods between business units consists of incomes for the selling department and cost for purchasing department. As it may be seen in the firms included in the scenario, transfer pricing is a method to insure tax shield/ benefit for the group firms or international firms through intercompany profit transfer. With this method, if the firms would not make such adjustments it is seen evidently that the government and accordingly the entire society will be affected in negative manner. As it is specified in the analysis of the firms included in the scenario the firms being subject to different tax ratios may cause tax losses easily. In a system where no adequate supervision or accounting expertness is available, it would be easy for the firms to obtain more profits and have competitive advantage over their rivals. As it may be seen from the example, in the event of failure to make the adjustment the society will be subject to loss of $\$ 8,400$.

Regulatory bodies should employ more careful and skilled auditors in order to prevent any problem which may occur in this subject. The latest IT applications and in particular e-technologies should have more place in the accounting system. Activities aimed at raising awareness and consciousness of the executors and auditors about transfer pricing should be promoted. It should be noted that transfer pricing is used as transfer of wealth to abroad, which should be retained in a country. Therefore, financial transactions related to profit transfers should be controlled. Sharing of the comparative (arms length) prices by the public at catalogue level shall have reducing effects on transfer pricing application. Studies should be conducted on this topic. In adjustment of the accounting records, the tax base amount 
should be corr3ected through using the off balance accounts. In this manner, deductible income element shall occur for the affiliate, and non-deductible income shall occur for the parent company. With the accounting entrances of such two elements transfer pricing adjustment transactions would be completed. Then, the applicable documents and certificates shall be prepared and notified.

\section{References}

Abdallah, W. M. (2004. Critical Concerns in Transfer Pricing and Practice, London; Praeger Publishers.

Adams, L. \& Drtina, R. (2008). Transfer Pricing for Aligning Divisional and Corporate Decisions, Business Horizons, 51, 411-417. http://dx.doi.org/10.1016/j.bushor.2008.03.008

Alfons, J. W. (2009) Profit Shifting in the EU: Evidence from Germany, International Tax and Public Finance, 16 (3), 281-297. http://dx.doi.org/10.1007/s10797-008-9068-x

Anctil, R. M. \& Dutta S. (1999) Negotiated Transfer Pricing and Divisional vs. Firm-Wide Performance Evaluation, The Accounting Review, 74 (1), 87-104. http://dx.doi.org/10.2308/accr.1999.74.1.87

Baldenius, T., Melumad, N. \& Reichelstein S. (2004). Integrating Managerial and Tax Objectives in Transfer Pricing, The Accounting Review, 79 (3), 591- 615. http://dx.doi.org/10.2308/accr.2004.79.3.591

Borkowski, S. C. (1997). The Transfer Pricing Concerns of and Developing Countries, The International Journal of Accounting, 32(3), 321-336. http://dx.doi.org/10.1016/S0020-7063(97)90014-5

Burns, J. O. (1980). Transfer-Pricing Decisions in U. S. Multinational Corporations, Journal of International Business Studies, 10(Fall), 23-39. http://dx.doi.org/10.1057/palgrave.jibs. 8490603

Eden, L. (1983) Transfer Pricing Policies under Tariff Barriers, Canadian Journal of Economics, 16(November), 669-685. http://dx.doi.org/10.2307/135047

Chan, K. \& Hung - Chow, L.(1997). An Empirical Study of Tax Audits in China on International Transfer Pricing", Journal of Accounting \& Economics, 23, 83-112. http://dx.doi.org/10.1016/S0165-4101(96)00445-4

Clausing, K. A. (2003).Tax-Motivated Transfer Pricing and U.S. Intrafirm Trade Prices, Journal of Public Economics, 87, 2207-2223. http://dx.doi.org/10.1016/S0047-2727(02)00015-4

Cravens, S.K. (1997). Examining The Role Of Transfer Pricing As A Strategy For Multinational Firms, International Business Review, 6 (2), 127-145. http://dx.doi.org/10.1016/S0969-5931(96)00042-X

Elliott, J. \& Emmanuel, C. (2000).International Transfer Pricing: Searching for Patterns, European Management Journal, 18(2), 216-222. http://dx.doi.org/10.1016/S0263-2373(99)00093-6

Garrison,R \& Noreen,E. (2013) Managerial Accounting, McGrew-Hill, USA

Grabski, S. V. (1985). Transfer Pricing in Complex Organisations: A Review and Integration of Recent Empirical and Analytical Research, Journal of Accounting Literature, 4, 33-75.

Halperin, R. \& Srinidhi, B. (1987). The Effects of the U. S. Income Tax Regulation's Transfer-Pricing Rules on Allocative Efficiency, The Accounting Review, 62(October), 668-706.

Hongren C.T., Datar, S. M. \& Rajan M. (2011).Cost Accounting A Managerial Emphasis, Printice Hall

Li, D. \& Ferreira, M.P. (2008). Internal and external factors on firms' transfer pricing decisions: insights from organization studies, Notas Economicas, Junho, 23-38.

Prusa, T. J. (1990). An Incentive Compatible Approach to the Transfer Pricing Problem, Journal of International Economics, 28, 155-172. http://dx.doi.org/10.1016/0022-1996(90)90054-P

Samuelson, L. (1982). The multinational firm with arm's length transfer price limits. Journal of International Economics, 13(3-4), 365-374. http://dx.doi.org/10.1016/0022-1996(82)90064-2

Smith, M. (2002) Tax and Incentive Trade-Offs in Multinational Transfer Pricing, Journal of Accounting, Auditing \& Finance, 17(3), 209-236.

Tippet, M. \& Wright, B. (2006). The Teaching of Transfer Pricing: Theory and Examples, Journal of Accounting Education, 24, 173-196. http://dx.doi.org/10.1016/j.jaccedu.2006.05.002

International Accounting Standart 36: Impairment of Assets

Wong, H., Nassiripour, S., Mir, R. \& Healy, W. (2011). Transfer Price Setting in Multinational Corporations, International Journal of Business and Social Science, 2(9), 10-14. 